\title{
A Packet Discarding Method with Two Parameters
}

\author{
Atsuro Fujii Non-member (Okayama Prefectural University, fujii221@c.oka-pu.ac.jp) \\ Hiroshi Inai Member (Okayama Prefectural University, inai@c.oka-pu.ac.jp)
}

Keywords: Packet Discarding, Active Queue Management, Random Early Detection, Routers

In order to avoid congestion in the network and to achieve a fair share of the resource among communication flows, the packet discarding method called RED (Random Early Detection $)^{(1)}$ has been proposed. In that method, a router randomly discards arriving packets before its buffer overflows. Although some enhanced methods of RED, such as Flow RED $^{(2)}$, Balanced RED, Stabilized RED, Adaptive RED, Easy $\mathrm{RED}^{(3)}$ and so on, have been proposed, they (except for Easy RED) employ complicated controls to achieve high throughput and fairness among communication flows. However, many control parameters in the complicated methods would prevent from reaching their practical stages. This paper proposes a simple packet discarding method which reduces the number of parameters and provides better performance than existing ones.

The proposed method omits the probabilistic packet discard from RED. The discarding algorithm is as follows. In the same way as RED, at every packet arrival, the router calculates a moving average of the queue length avg,

$$
\text { avg } \longleftarrow \begin{cases}\left(1-w_{q}\right) \text { avg }+w_{q} q & (q \neq 0) \\ \left(1-w_{q}\right)^{m} \text { avg } & (q=0)\end{cases}
$$

where $q, w_{q}$ and $m$ are the current queue length, the queue weight, and the queue idle period, respectively. If avg is less than or equal to the threshold $\max _{t h}$, then the router discards the arriving packet, otherwise the router stores the packet. Note that the arriving packet will be discarded when the buffer is full.

In order to evaluate the performance of our method, we execute simulation with a single bottleneck link in a dumbbell topology. Figures 1 and 2 respectively show influence of $w_{q}$ and $\max _{t h}$ on the total throughput, where $K$ in Fig. 2 is the buffer size of the congested router. Too large or too small $w_{q}$ degrades the throughput performance. Under a

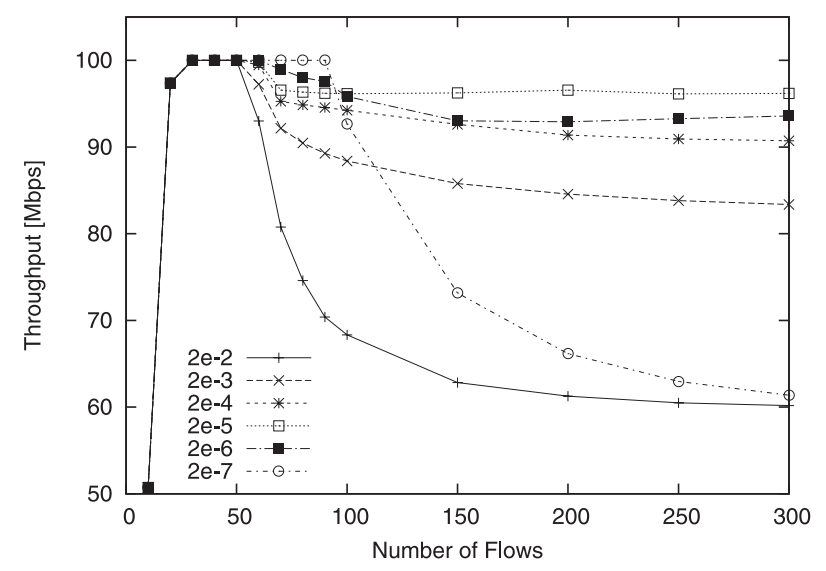

Fig. 1. Influence of $w_{q}$ on the throughput. large $w_{q}$, our method acts like a drop tail with the buffer size $\max _{t h}$. For a small $w_{q}$, the buffer would become full before avg reaches the threshold. On the other hand, $\max _{t h}$ has a slight influence on the throughput.

Fig. 3 shows a comparison of the throughput. The proposed method outperforms the existing ones.

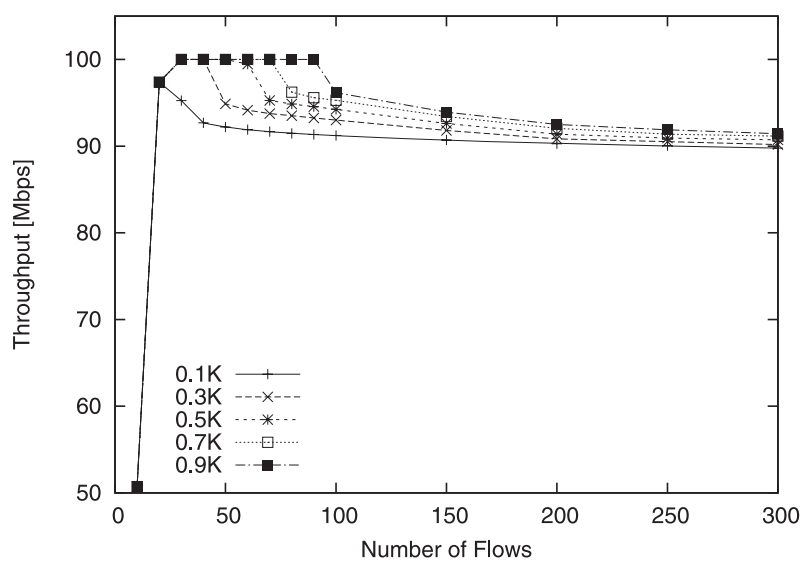

Fig. 2. Influence of $\max _{t h}$ on the throughput.

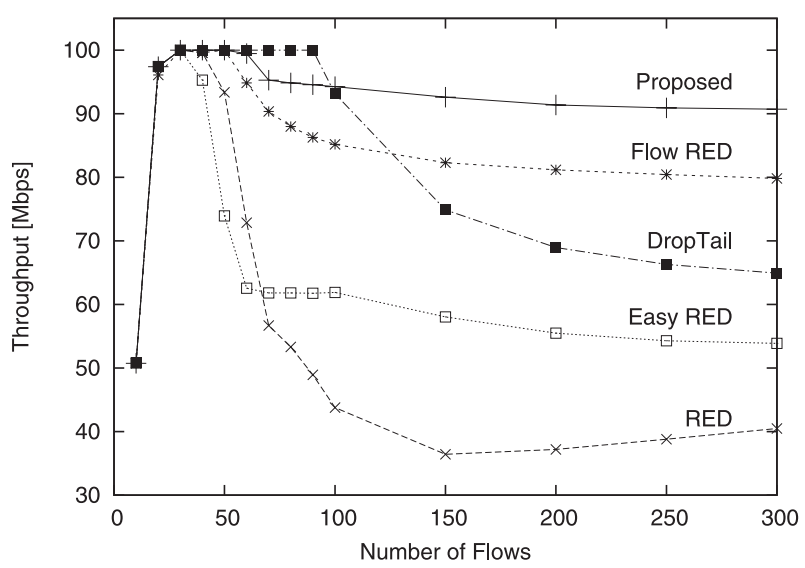

Fig. 3. Comparison of the throughput.

\section{References}

(1) S. Floyd and V. Jacobson: "Random Early Detection Gateways for Congestion Avoidance", IEEE/ACM Transactions on Networking, Vol.1, No.4, pp.397-413 (1993-8)

(2) D. Lin and R. Morris: "Dynamics of Random Early Detection", ACM SIGCOMM Computer Communication Review, Vol.27, No.4, pp.127-137 (1997-10)

(3) L. A. Grieco and S. Mascolo: "TCP Westwood and Easy RED to Improve Fairness in High-Speed Networks", Protocols for High Speed Networks, LNCS 2334, pp.130-146, Springer (2002) 


\title{
パラメータの少ないパケット廃棄方式
}

\author{
非会員 藤井 敦朗* 正 員 稲井＼cjkstart寛*
}

\author{
A Packet Discarding Method with Two Parametrers
}

Atsuro Fujii*, Non-member, Hiroshi Inai*, Member

\begin{abstract}
In order to avoid congestion in the network and to achieve a fair share of the resource among communication flows, the packet discarding method called RED (Random Early Detection) has been proposed. In that method, a router randomly discards arriving packets before its buffer overflows. Although some enhanced methods of RED have been proposed, they employ complicated controls to achieve high throughput and fairness among communication flows. However, many control parameters in the complicated methods would prevent from reaching their practical stages. This paper proposes a simple packet discarding method which reduces the number of parameters and provides better performance than existing ones. Concretely speaking, our method omits the probabilistic packet discard from RED. Via simulation, the proposed method provides higher throughput than existing ones and almost equal fairness.
\end{abstract}

キーワード：パケット廃棄, 能動的キュー管理, Radom Early Detection, ルータ

Keywords: Packet Discarding, Active Queue Management, Radom Early Detection, Routers

\section{1. はじめに}

近年, インターネットの利用者の増加に伴いネットワー ク上のトラヒックも増大している。ネットワーク内で輻輳 が発生し，ルータのバッファが満杯になると，そのルータ に到着したパケットは廃棄される。このように自然なパケッ 卜の廃棄を後方廃棄（Drop Tail）という。パケット廃棄が 発生すると，TCPによる通信では，送信ホストは輻輳解 消のためにウィンドウサイズを減少させて，送信レートを 下げる。そのため，輻輳により，多くの送信ホストがほぼ 同時に送信レートを下げ，ネットワーク全体のスループッ トが大幅に低下することが報告されている ${ }^{(2)}$ 。また，バッ ファが満杯のとき偶然に到着したパケットが廃棄されるこ とは, フロー間の公平性を損なう要因となっている。特に バースト性の高いトラヒックの場合には，ある特定のフロー に属するパケットのみが廃棄される恐れがある。そもそも 廃棄されるべきは輻輳を招いたフローに属するパケットで あり，輻輳時に到着したパケットではない。そこで，ルー 夕のバッファ溢れが発生する前に当該ルータが到着パケッ トをランダムに廃棄することで輻輳を回避し, フロー間の

* 岡山県立大学情報工学部情報通信工学科

T 719-1197 岡山県総社市窪木 111 番地

Department of Communication Engineering

Okayama Prefectural University

111, Kuboki, Soja, Okayama 719-1197
スループットの公平性をも確保する RED (Random Early Detection) (3) が考案された。

RED には, Flow RED ${ }^{(4)}$, Balanced RED ${ }^{(5)}$, Stabilized RED ${ }^{(6)}$, Adaptive RED ${ }^{(7)}$, Easy RED ${ }^{(8)}$ などの 様々な改良版が提案されている。これらの方式の中では, フ ローごとのキュー長を制御する Flow RED が最も高いス ループットを示すことが報告されている (9)。しかし, Easy $\mathrm{RED}$ 以外の方式では数多くのパラメータを調整する必要 があり，実運用が難しいという問題が考えられる。その一 方で, Easy RED はREDのパラメータを削減した簡潔な 方式であるが, この方式は時々刻々と変動するルータ内の 実キュー長により到着パケットの廃棄を判断しているため, キュー長の急激な変化の影響を受け易く, 実質的に後方廃棄 と同様の状態に陥る恐れがある。そこで, 本研究では, RED より少ない数のパラメータで RED や Flow RED と同等以 上のスループット，公平性を実現する方式を提案する。

以下， 2 章では，既存方式の概要と問題点を述べ，新た な方式を提案する。3 章では, パケット廃棄方式の性能を 評価するためのシミュレーションモデルを構築する。4 章 では, シミュレーションにより，パラメー夕值が提案方式 の性能に及ぼす影響について考察する。5 章では, 既存方 式との性能比較を行って, 提案方式の有効性を示す。最後 に 6 章で, 本研究で得られた結果のまとめと今度の課題に ついて述べる。 


\section{2. パケット廃棄方式}

本節では, 後の章で性能比較の対象とした RED, Flow RED, Easy RED の概要と問題点を述べた後, Easy RED とは異なる視点でパラメータを削減した場合について考察 し，改良方式を提案する。

$\langle\mathbf{2} \cdot \mathbf{1}\rangle \mathrm{RED} \mathrm{RED}^{(3)}$ は, まず, 当該ルー夕内の平均 キュー長 $a v g$ を算出する。 $a v g$ は実キュー長 $q$ の移動平均 で, 重み係数を $w_{q}$ とすると, 次式のように表される。

$$
a v g \longleftarrow \begin{cases}\left(1-w_{q}\right) \text { avg }+w_{q} q & (q \neq 0) \\ \left(1-w_{q}\right)^{m} \text { avg } & (q=0)\end{cases}
$$

但し， $m$ はキューが最後に空になってから現在までの経過 時間である。平均キュー長 $a v g$ はパケットが到着するたび に更新される。

次に, 平均キュー長 $a v g$ に基づいて, 到着パケットを廃 棄する確率（以降，廃棄確率という） $p_{a}$ を次式のように決 定する。

$$
p_{a}= \begin{cases}0 & \left(0<\text { avg }<\min _{t h}\right) \\ \frac{p_{b}}{\left(1-\text { count } \times p_{b}\right)} & \left(\text { min }_{t h} \leq a v g \leq \max _{t h}\right) \\ 1 & \left(\text { max }_{t h}<\text { avg }\right)\end{cases}
$$

ここで, $\min _{t h}, \max _{t h}$, count はそれぞれキュー長に関 する下段の閾值，上段の閾値，最後に廃棄を行ってからバッ ファに格納されたパケット数である。また, $p_{b}$ は次のよう に与えられる。

$$
p_{b}=\frac{a v g-\min _{t h}}{\max _{t h}-\min _{t h}} \max _{p}
$$

尚, $\max _{p}$ は $p_{b}$ の最大值である。

RED のパラメータは $w_{q}, \min _{t h}, \max _{t h}, \max _{p}$ の 4 つであり，他の avg, $q, m, p_{a}, p_{b}$, count は変数である。 RED はバッファが溢れる前からパケットを確率的に廃裹 し，特定のフローに属するパケットが連続的に廃棄されに くくすることによって，フロー間の公平性の維持を図って いる。また，複数のフローに属するパケットがほぼ同時に 廃棄されたときに全体のスループットが低下寸る現象の回 避も図っている。

$\langle\mathbf{2} \cdot \mathbf{2}\rangle \quad$ Flow RED Flow RED ${ }^{(4)}$ はフロー間の公平 性を向上することを目的として，RED を拡張した方式で ある。REDで扱う 4 つのパラメータに，フローごとのバッ ファ内パケット数の下段の閾值 $\min _{q}$ と上段の閾値 $\max _{q}$ の 2 つのパラメータが追加されている。これらのパラメー 夕の追加により，REDよりもさらにパラメータ調整が困難 になると考えられる。また，変数として，フローごとのバッ ファ内パケット数 $q$ len $n_{i}$ (但し, 添字の $i$ はフローID）と それらの平均 avgcq が追加されている。これらにより，フ ローごとのきめ細かなパケット廃裹を実現しているが，フ ロー数の増加に伴って変数の個数も増加する。

Flow RED におけるパケット廃棄は次のとおりである。 qlen $_{i} \geq \max _{q}$ または $q$ len $n_{i} \geq \operatorname{avgcp}$ のとき到着パケ ットを廃棄し, $\min _{t h} \leq a v g<\max _{t h}$ かつ qlen $_{i} \geq$ $\max \left[\min _{q}, a v g c q\right]$ のとき確率 $p_{a}$ で到着パケットを廃棄す る。また，avg< $\min _{t h}$ のとき到着パケットを格納する。 そして，これら以外のとき到着パケットを廃棄する。但し， 平均キュー長 $a v g$, 廃棄確率 $p_{a}$ は RED と同様の方法によ り算出する。また，フローごとのバッファ内パケット数の平 均 avgcq については, avg をバッファ内に現存するフロー 数 Nactiveで割った值が用いられている。

$\left\langle\mathbf{2 \cdot 3 \rangle}\right.$ Easy RED Easy RED ${ }^{(8)}$ は RED を簡素化 したパケット廃棄方式である。平均キュー長 avg 廃止し, 実キュー長 $q$ により輻輳の度合いを判断することとしてい る。これに伴って, 上段の閾值 $\max _{t h}$ も廃止されている。 $\max _{t h}$ は強制廃棄ラインであり, 実キュー長が $\max _{t h}$ に 達すると到着パケットを廃書することにすると, バッファ サイズを $\max _{t h}$ とする後方廃棄と同様となってしまうため である。さらに，廃棄確率を固定值としている。これらの 簡素化により, パラメー夕は下段の闇值 $\min _{t h}$ と廃充確率 pdrop の 2 つのみ, 変数は実キュー長 $q$ の 1 つのみとなっ ている。

Easy RED におけるパケット廃衰は次のとおりである。 $q \leq$ min $_{t h}$ のとき到着パケットをバッファに格納し,$q>$ min $_{\text {th }}$ のとき確率 pdrop で到着パケットを廃棄する。但し, キュー溢れの場合には到着パケットは廃棄される。

Easy RED では，実キュー長が min $_{t h}$ を超えると確率 的な廃棄を行って輻輳回避を図るが，フロー数の増加など によってキュー長が急激に増加してバッファサイズに近づ いた場合には，実質的に後方廃棄と同様の状態に陥る恐れ がある。

$\langle 2 \cdot 4\rangle$ RED のパラメータ削減＼cjkstart前節で述べたよう に, Easy RED には後方廃棄と同様の現象が起こり得ると いう問題がある。これは, Easy RED が実キュー長 $q$ を輻 輳の判断に用いていることに起因している。そこで，平均 キュー長 $a v g$ を残し，その一方で，下段の䦐值 $\min _{t h}$ を 廃止して，上段の䦭値 $\max _{t h}$ を残すことを考える。これに より, 到着パケットの確率的な廃裹が行われなくなるため, 当該ルー夕を通過するフロー間の公平性が低下する恐れが ある。しかし，その一方で，バッファに余裕があるにもか かわらず確率的な廃裹が起こることがなくなるため, 各フ ローが必要以上に送信レートを下げることがなくなり， ス ループットの向上が期待できる。

ここで，RED において到着パケットの確率的な廃棄を 行う場合と行わない場合で，フローごとの廃棄パケット数 に生じる偏りについて検討する。尚, 確率的な廃棄を行わ ない場合とは, $p_{b}=0$ と固定して RED を運用することに 相当する。後の 3 章で述べるモデルのシミュレーションを 行って, $100[\mathrm{Mbps}]$ のボトルネック回線に 100 本のフロー が集まったときのフローごとの廃棄パケット数を計測した。 尚，RED のパラメータ值については，5の冒頭にあげた数 值を用いている。 
横軸をフローID とし，縦軸を廃棄されたパケット数と するグラフを図 1,2 に示す。眓から，確率的な廃棄を行 わない場合では廃棄されるパケット総数は多いが, 確率的 な廃棄を行う場合と比較して，フローごとに廃棄されるパ ケット数にはそれほど大きな偏りはないことがわかる。こ のことは，確率的な廃棄を行わなくても高い公平性を実現 することが可能であることを示していると考えられる。し かし，全体の廃棄数が多いことはスループットの低下につ ながる恐れがあるため, 強制廃棄ラインである $\max _{t h}$ を調 整する必要があると思われる。

$\langle\mathbf{2} \cdot \mathbf{5}\rangle$ 提案方式 前節の検討に基づいて，次のよう なパケット廃棄方式を提案する。

まず, RED と同様の方法で平均キュー長 $a v g$ を算出す る。そして,$a v g \leq \max _{t h}$ のときに到着パケットをバッ ファに格納し,$a v g>\max _{t h}$ のときに到着パケットを廃棄 する。但し, キュー溢れの場合には到着パケットは廃棄さ れる。

このような簡素化により，提案方式では，パラメータは 重み係数 $w_{q}$ と上段の閾值 $\max _{t h}$ の 2 つのみとなる。

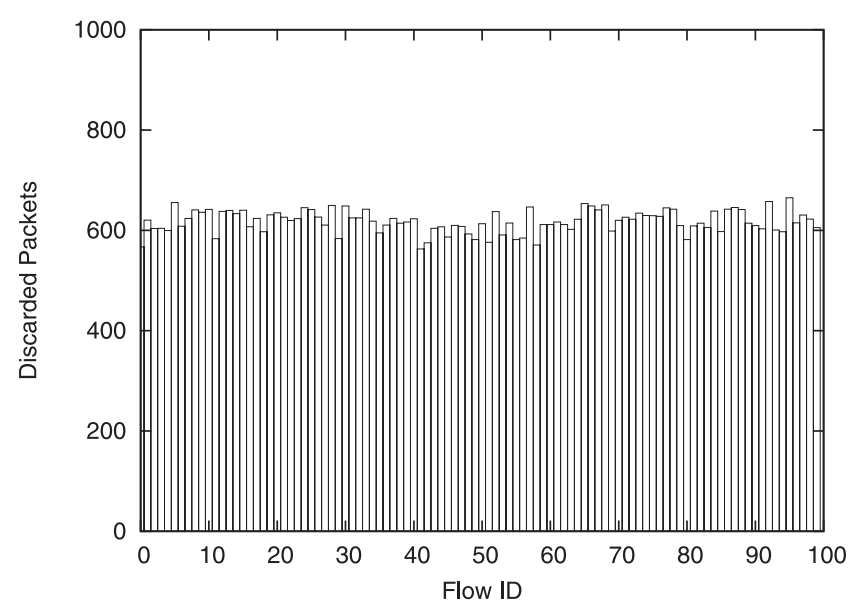

Fig. 1. The number of discarded packets per flow when a router discards packets probabilistically.

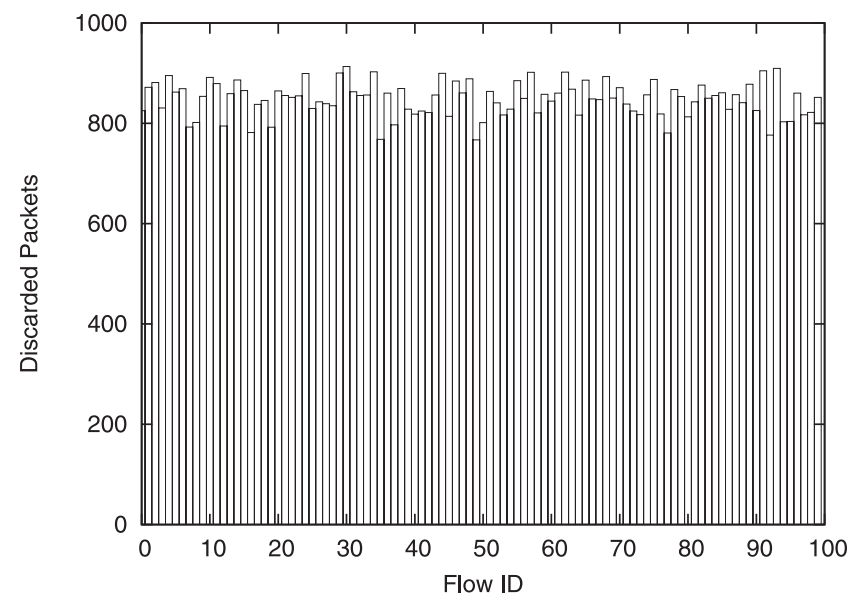

Fig. 2. The number of discarded packets per flow when a router discards packets deterministically.
提案方式は, RED において $p_{b}=0$ とすることにより, $\min _{t h}$ と $\max _{p}$ の 2 つのパラメータを無効にした方式であ る。これにより, 確率的な廃棄は行われない。REDのパ ラメータ調整に関する既存の研究 ${ }^{(10)(11)}$ では, 4 つのパラ メータが機能していることが前提となっており，いくつか のパラメータを無効とする設定での評価は行われていない。 これは, 平均キュー長に応じて線形的に変化する廃棄確率 に基づいた確率的廃棄を行うという RED の特徴を維持す るためと考えられる。

\section{3. シミュレーションモデル}

パケット廃棄方式の性能を評価するため, 図 3 のような ダンベル型ネットワークを考える。ダンベル型ネットワー クモデルでは, ボトルネックとなる回線で接続された 2 台 のルータを介して, 複数ペア（図ではペア数を $N$ としてい る）の送受信端末が通信を行う。ダンベル型ネットワーク モデルは，文献 (6) (7) など数多くの文献で用いられている 性能評価モデルであり, 文献 $(3) \sim(5)$ などで用いられてい る漏斗型ネットワーク（複数の端末が 1 台のルータを介し て1台のサーバに接続されているネットワークで, ルータサーバ間の回線がボトルネックとなる）と本質的に同様の モデルである。

本モデルでは，各回線の伝送速度はすべて等しく 100 $[\mathrm{Mbps}]$ としている。また, 全ての送受信端末はTCP Reno で通信を行うものとしている。1つの送受信ぺアで 1 つの フローを持つこととしているため, ペア数 $N$ がフロー数と なっている。各送信側端末とルータ 1 間の遅延, ルータ 2 と 各受信側端末間の遅延は 10 50 [msec] の範囲でランダム に与えている。また, ルータ 1-2 間の伝播遅延は無視できる ほど小さいものとしているため，ルータ間の遅延はパケッ 卜送出に要する時間となる。各送信側端末が送信を開始す る時刻は 1 ～ $10[\mathrm{sec}]$ の間でランダムとし, シミュレーショ ン時間を $100[\mathrm{sec}]$ としている。以降の章に示す数值例では, キュー長の過渡的な変化を表す図 4〜 7 以外は, $100[\mathrm{sec}]$ の シミュレーションを 30 回実行して得られた平均值を示して いる。また, 簡単のため, パケットサイズを 1 [KByte] の 固定長とし，ルータのバッファサイズ $K=5$ [MByte] と

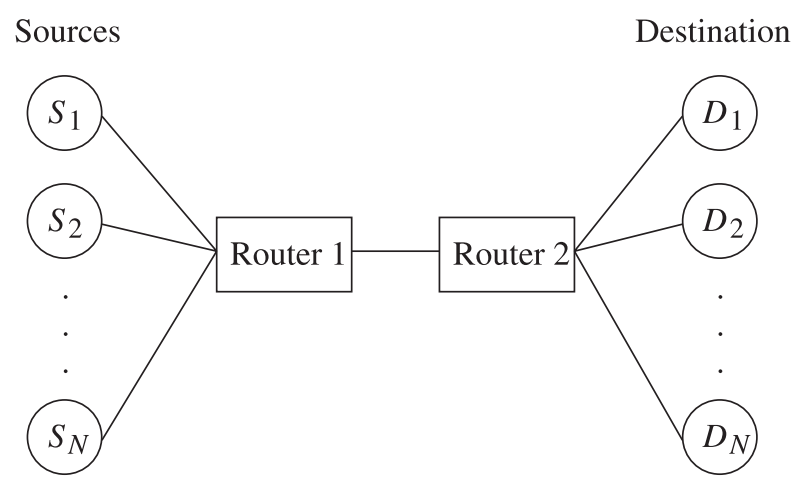

Fig. 3. Simulation model. 


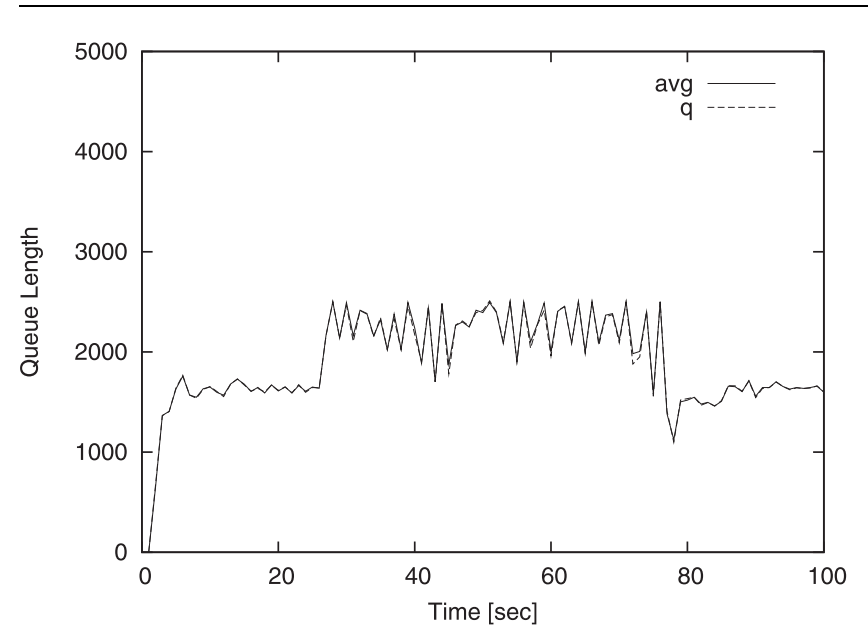

Fig. 4. Transition of queue length $\left(w_{q}=2 \times 10^{-2}\right)$.

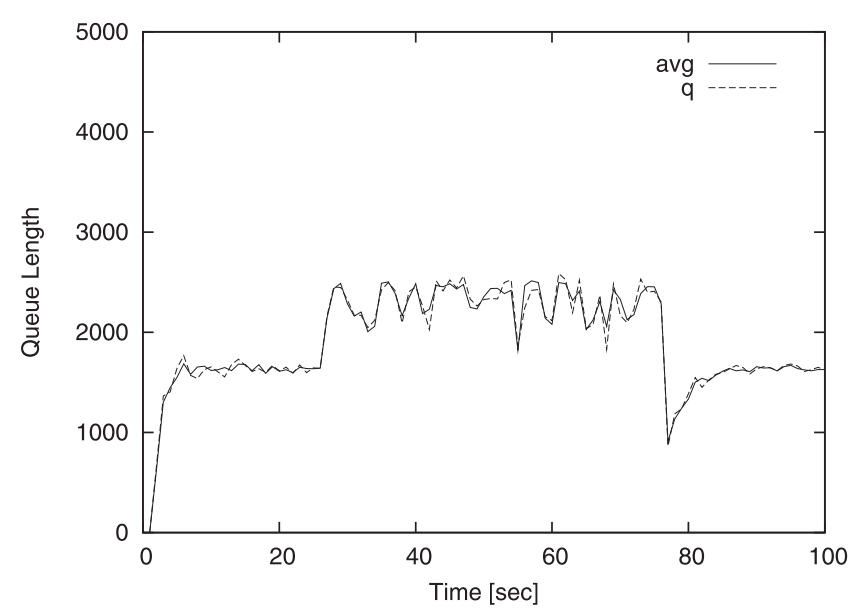

Fig. 5. Transition of queue length $\left(w_{q}=2 \times 10^{-3}\right)$.

している。したがって，ルータのバッファには 5000 個のパ ケットを収容することができる。輻輳が発生する可能性の ある前段のルータ 1 でパケット廃棄方式を実行することと して, シミュレーションを行った。

\section{4. パラメータ值が性能に及ぼす影響}

提案方式では 2 つのパラメータ $w_{q}, \max _{t h}$ を用いてい る。本節では, シミュレーションにより，これら 2 つのパラ メータ值が提案方式の性能に及ぼす影響について考察する。

$\langle\mathbf{4} \cdot \mathbf{1}\rangle$ 重み係数 $\boldsymbol{w}_{\boldsymbol{q}}$ の影響 $\quad w_{q}$ は平均キュー長 $a v g$ の算出時に使用する重み係数である。 $w_{q}$ の值が大きすぎる と, 実キュー長 $q$ と平均キュー長 $a v g$ の值がほぼ等しくな るため, 実質的には， $\max _{t h}$ に等しいバッファサイズで後 方廃棄を行っていることになる。また， $w_{q}$ の值が小さすぎ ると, 実キュー長の急激な変化に対応しづらくなる。特に, 実キュー長が急激に増加すると，平均キュー長が $\max _{t h}$ を 超える以前にバッファ溢れが発生して, 結果的に後方廃棄 と同様の性能となる恐れがある。

まず， $w_{q}$ が実キュー長 $q$ と平均キュー長 $a v g$ に及ぼす 影響を調べるため, 時間帯によりフロー数を変化させて, シミュレーションを行った。図 $4 \sim 7$ に, フロー数を 0〜

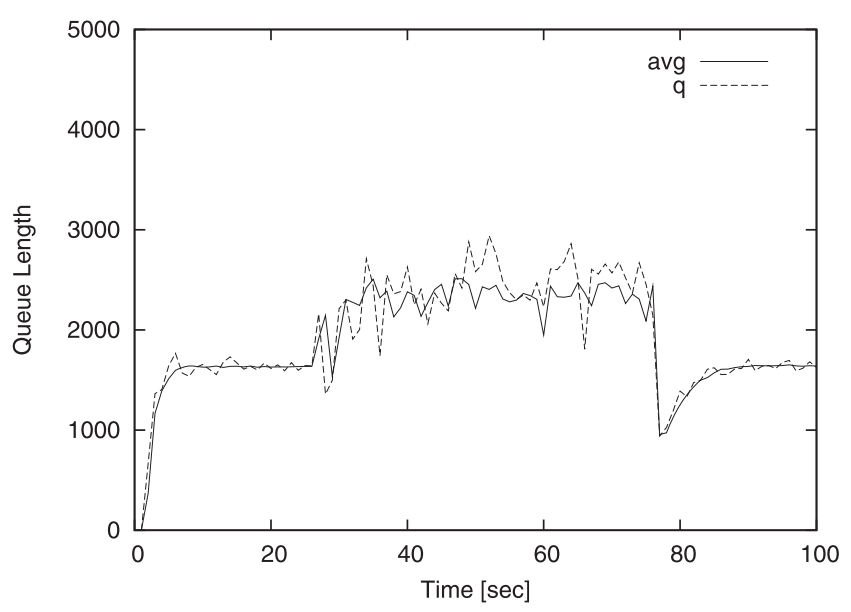

Fig. 6. Transition of queue length $\left(w_{q}=2 \times 10^{-4}\right)$.

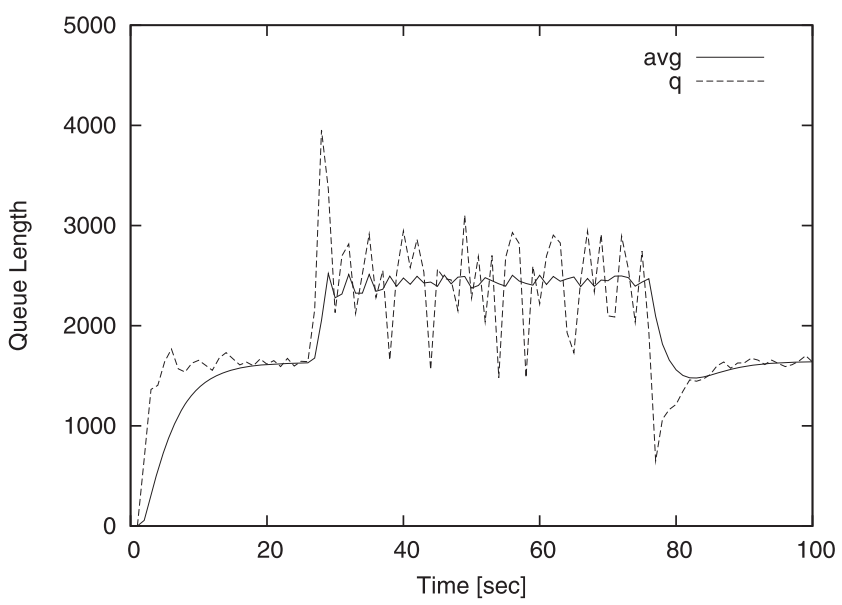

Fig. 7. Transition of queue length $\left(w_{q}=2 \times 10^{-5}\right)$.

25 [sec] では 50, 25〜 75 [sec] では 100, 75〜100 [sec] で は 50 とした場合のキュー長の推移を示す。尚, ここでは, $w_{q}=2 \times 10^{-x}(x=2,3,4,5)$ の場合の結果を示してい るが, これは, 文献 (3) で使われている代表的な数值例が $w_{q}=0.002$ となっていたため, その 10 倍から 1/100まで について調べている。図 4〜7 の縦軸はルータ 1 のバッファ 内パケット数 (以降, キュー長という), 横軸はシミュレー ション時刻を表している。また, $\max _{t h}=0.5 K$ としてい る。但し， $K$ はバッファサイズである。 $\max _{t h}=0.5 K$ と いうのも, 文献 (3) で使われている代表的な数值例である。

図から $w_{q}$ が小さくなるにつれて, 平均キュー長 (実線) と実キュー長 (破線) のずれが次第に大きくなっている。こ のずれによって, 実キュー長が $\max _{t h}$ を超えていても廃㶳 が起こらない場合やその逆の場合が起こり得るため, 確率 的な廃棄と似た効果を期待することができると考えられる。 しかし, 図 7 のように $w_{q}$ が小さくなり過ぎると, フロー 数が変化したときに平均キュー長と実キュー長が大きくず れてしまう。特に，フロー数が増加したときの実キュー長 のオーバシュートが大きくなると, バッファ溢れによる廃 棄が起こるため, 実質的に後方廃裹と同様の現象が起こる 可能性が高くなる。 


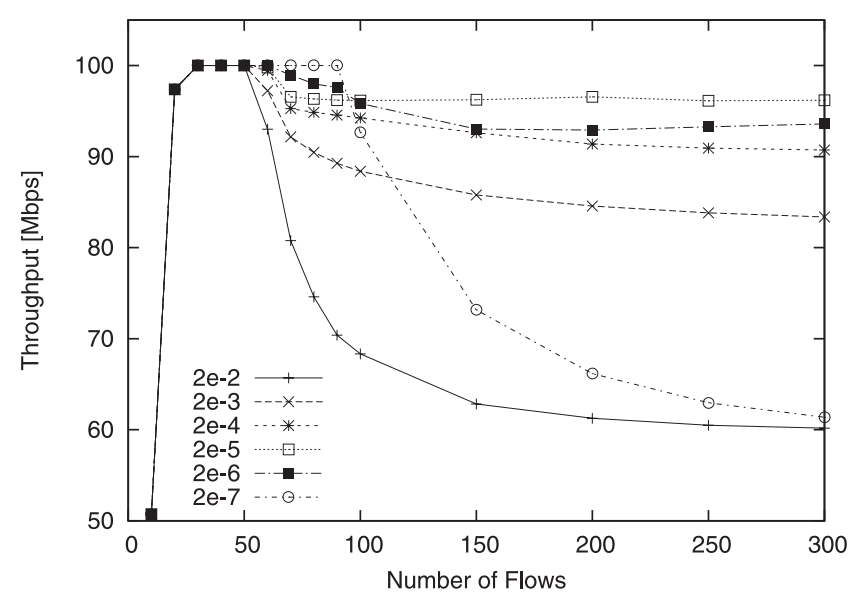

Fig. 8. Influence of $w_{q}$ on the throughput.

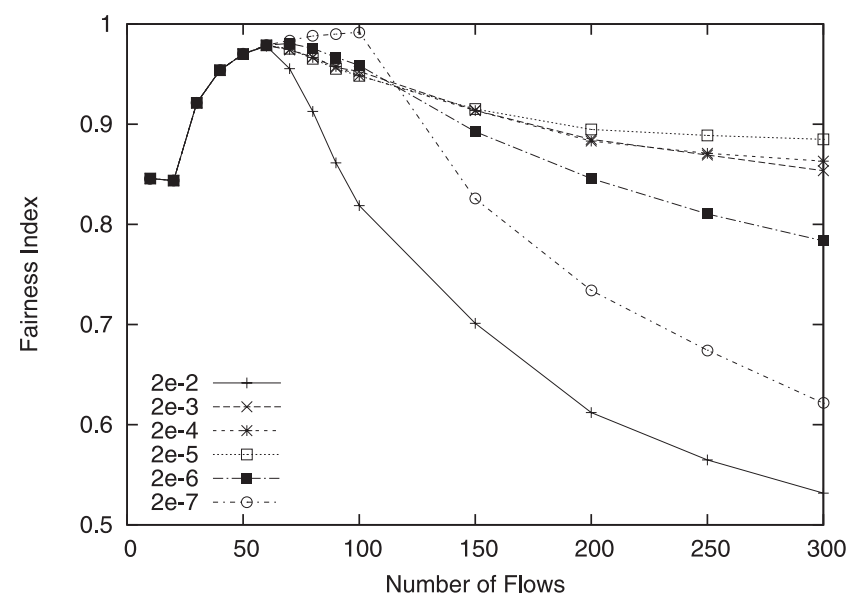

Fig. 9. Influence of $w_{q}$ on the fairness index.

次に, $w_{q}$ を $2 \times 10^{-2}$ から $2 \times 10^{-7}$ へと $1 / 10$ 倍ずつ 変化させて, 各フローのスループットの合計（以降，単に スループットという）と各フローのスループット間の公平 性（以降，単に公平性という）を測定した結果をそれぞれ 図 8,9 に示す。図の縦軸はスループットまたは公平性，横 軸はフロー数を表している。フロー数については，シミュ レーションの途中で変化させることなく，横軸で示された 值に固定している。尚, $\max _{t h}$ をバッファサイズ $K$ の 0.5 倍としている。

公平性の評価については, 次に示す Fairness Index ${ }^{(1)}$ 用いることにする。

$$
\text { FairnessIndex }=\frac{\left(\sum_{i=1}^{N} \gamma_{i}\right)^{2}}{N \sum_{i=1}^{N} \gamma_{i}^{2}}
$$

ここで, $N$ はフロー数, $\gamma_{i}$ はフロー $i(i=1,2, \cdots, N)$ の スループットである。Fairness Index は 0 以上 1 以下の值 をとり, 全ての $\gamma_{i}$ が等しいときに 1 となるので, 1 に近い ほど各フロー間の公平性が高くなる。

図 8,9 から,$w_{q}=0.02$ のように $w_{q}$ が大きい場合には,
平均キュー長が実キュー長にほほ等しくなるため, 実質的に バッファサイズ $0.5 K$ のときの後方廃棄となり, スループッ 卜，公平性とも低い值を示している。一方， $w_{q}=2 \times 10^{-7}$ のように $w_{q}$ が小さい場合には, 実キュー長の変化が平均 キュー長にほとんど反映されなくなるため, 平均キュー長 が $\max _{t h}$ を超える以前にバッファ溢れによるパケット廃棄 が発生し，スループット，公平性とも低い值を示している。 ここで示した数值例で最も高いスループットと公平性を示 したのは $w_{q}=2 \times 10^{-5}$ の場合である。しかし, 前述の図 7 によると, $w_{q}=2 \times 10^{-5}$ のときには, フロー数が増加し たときの実キュー長のオーバシュートが大きいため, バッ ファサイズによっては, バッファ溢れによるパケット廃棄 が発生することが考えられる。そこで, 以降の数值例では, $w_{q}=2 \times 10^{-4}$ とする。

$\langle\mathbf{4} \cdot \mathbf{2}\rangle$ 閾值 $\boldsymbol{m a x}_{\boldsymbol{t h}}$ の影響 $\quad \max _{t h}$ は平均キュー長 に対する閾值で, 平均キュー長がこの值を超えた時に到着 パケットは廃棄される。したがって, $\max _{t h}$ が小さすぎる と, 必要以上にパケットを廃棄して, スループットを低下 させる恐れがある。一方，大きすぎると，平均キュー長が $\max _{t h}$ を超える以前にバッファ溢れを起こしてしまい, 実 質的に後方廃棄と同様の状態に陥る可能性が高くなる。

$w_{q}=2 \times 10^{-4}$ とし, $\max _{t h}$ をバッファサイズ $K$ の 0.1〜0.9 倍と変化させてシミュレーションを行った結果を 困 10, 11 に示す。これらの図の縦軸, 横軸については前節 の図 8,9 と同様である。フロー数が増加し, 閾值 $\max _{t h}$ による廃棄が起こり始めるとスループットが低下し，それ に伴って公平性も低下する。しかし， $\max _{t h}$ はスループッ トや公平性が下がり始めるフロー数に影響を及ぼすだけで, フロー数が非常に多くなると, $\max _{t h}$ が性能に及ぼす影響 はほとんどなくなっている。〈2・4〉節で行った検討では, 確 率的な廃棄を止めることにより, 廃棄パケット総数が増加 したことから，提案方式の運用に際してスループットを向 上させるためには, 䦨值 $\max _{t h}$ の調整が重要であるかのよ うに思われたが，本節と前節の結果から，平均キュー長の 重み係数 $w_{q}$ が及ぼす影響を重視する必要がある。

本節で得られた結果から， $\max _{t h}$ を大きめの值に設定す ることでスループット，公平性ともに向上するが, $\max _{t h}$ が小さいときと比べて，その利得はそれほど大きなもので はない。むしろ, 大きな值ではバッファ溢れを起こしやす くなるため, 注意が必要である。バッファサイズに依存す るが, $\max _{t h}$ の適正な值の候補として, RED における代 表的な值である $0.5 K$ を使うことが考えられる。

〈4·3〉 パラメータ数削減の効果 RED では 4 つ, そ して, その改良方式ではさらに多くのパラメータが用いら れている。パラメー夕数の増加に伴って, それらの值の組合 せ数が指数関数的に増大するため, パラメー夕設定に相当 な時間を費やすことになる。これに対して提案方式は，パ ラメータ数が 2 であり, 設定に要する時間の大幅な削減に 寄与している。

また，REDでは，ネットワーク条件の少しの変化に対し 


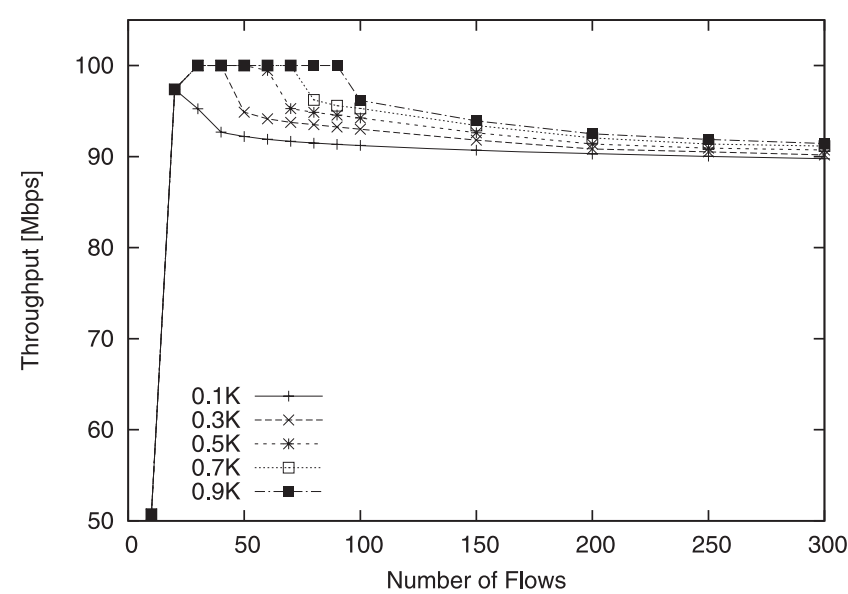

Fig. 10. Influence of $\max _{t h}$ on the throughput.

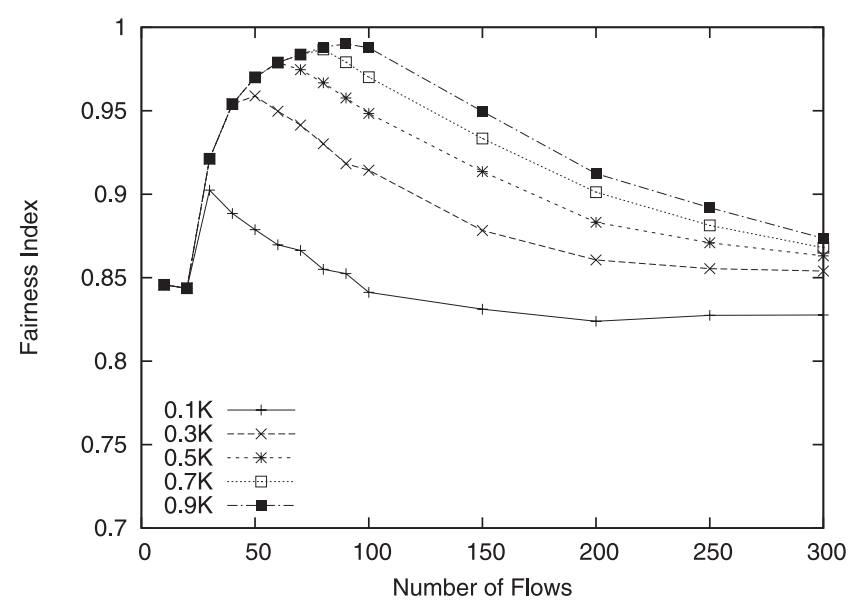

Fig. 11. Influence of $\max _{t h}$ on the fairness index.

て，適切なパラメー夕值が変動することが，文献 (10) (11) などで指摘されている。この問題の解決策として, パラメー 夕数を削減することが有効な場合がある。Easy RED では, パラメータ数を 2 とすることにより，上述のパラメータの 敏感性を改善している ${ }^{(8)}$ 。提案方式もパラメー夕数 2 であ るが, 図 8〜11に示したように, これら 2 つのパラメータ を適切に設定すると，フロー数が増加しても性能の低下を 抑えることが可能となる。

提案方式におけるパラメー夕調整については, 図 8〜11 より，閾值 $\max _{t h}$ よりも重み係数 $w_{q}$ の方が性能に及ぼす 影響が大きいため, $w_{q}$ の調整に重点を置く必要がある。そ の際に注意すべきは，図 6 に示したように，平均キュー長 と実キュー長の間に適度なずれを生じさせることで, 確率 的廃棄と同様の効果が得られ，その一方で，フロー数が急 激に増加した場合においても，実キュー長のオーバシュー トが抑えられるような值を $w_{q}$ に設定することである。

\section{5. 性能比較}

本章では, RED, Flow RED, Easy RED, 後方廃棄, 提案方式のスループット，公平性を比較する。既存方式の パラメータ值については, 各方式を提案している文献で用

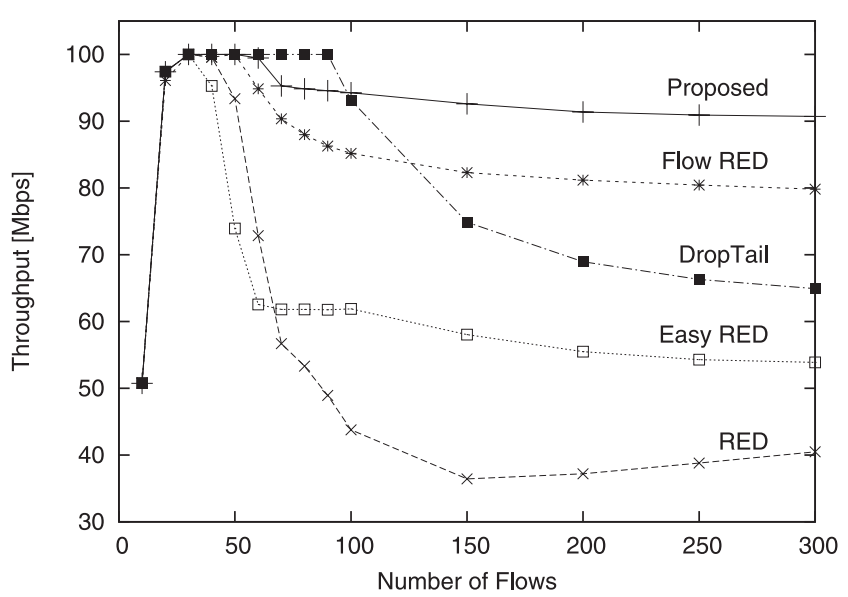

Fig. 12. Comparison of the throughput.

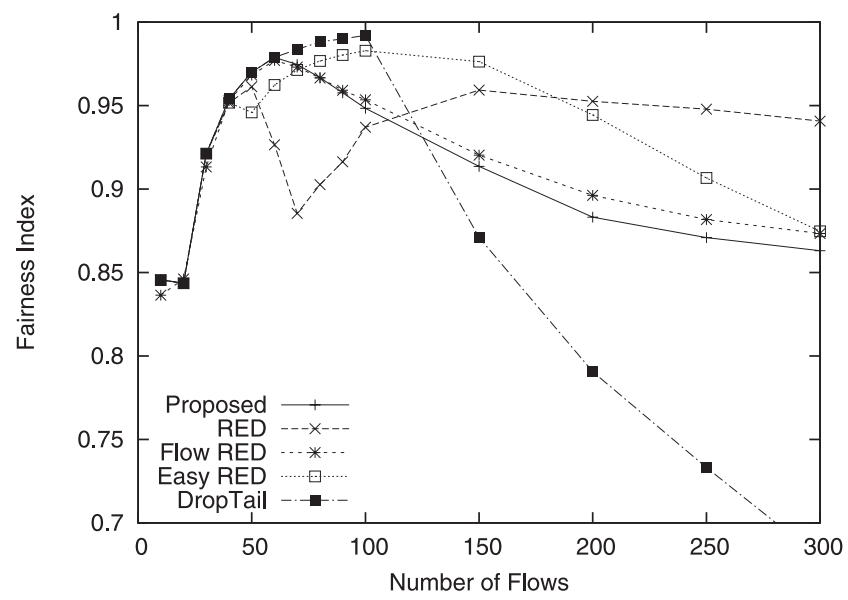

Fig. 13. Comparison of the fairness index.

いられている代表的な数值例や推奨値に基づいて, 次のよ うな値とした。 RED : $\min _{t h}=0.25 \mathrm{~K}, \max _{t h}=0.5 \mathrm{~K}$, $w_{q}=0.002, \max _{p}=0.02$ 。 Flow RED $: \min _{t h}=0.25 \mathrm{~K}$, $\max _{t h}=0.5 K, w_{q}=0.002, \max _{p}=0.02, \min _{q}=4$, $\max _{q}=0.4 K$ 。 Easy RED : $\min _{t h}=0.25 K$, pdrop $=$ 0.01。また, 提案方式のパラメー夕值については, 前章で 検討したとおり, $w_{q}=2 \times 10^{-4}, \max _{t h}=0.5 K$ として いる。各方式に扔けるスループット，公平性の比較をそれ ぞれ図 12,13に示す。図の縦軸はスループットまたは公平 性，横軸はフロー数を表している。

後方廃棄については，ここで示した数值例では，100 以 上のフロー数でバッファ溢れを起こし，スループットおよ び公平性が大きく低下している。しかし，バッファ溢れを 起こさなければ, 不必要な廃棄がないため, 最も高い性能 を示す方式である。

RED では, 確率的な廃棄が起こり始めるフロー数 50 あ たりからスループットが急激に低下している。さらにフロー 数が増加して平均キュー長がバッファサイズの $1 / 2$ になる と全ての到着パケットが強制的に廃棄されるため, さらに スループットが低下している。フロー数の増加に伴うスルー プットの減少とともに公平性も低下するが，フローごとの 
スループットが低い值で差が小さくなっていくため, やが て公平性が増加に転じている。

Flow RED はフローごとのキュー長がフローごとの閾值 を越えたときにパケットを廃棄するので，フローごとのス ループットのばらつきが抑えられて総スループットが高く なったと考えられる。公平性については，RED より低い值 を示しているが，RED に比べて高いスループットで公平性 を保っており，それほど問題とはならないと考えられる。

Easy RED では，実キュー長がバッファサイズの $1 / 4$ を 超えた時点で即座に確率的廃棄が行われており，他方式に 比べて早めに確率的な廃棄が起こっていると考えられるた め, スループットが下がり始めるフロー数が最も小さくなっ ている。しかし，それ以上フロー数が増加してもバッファ 溢れが起こらない限り確率的廃棄しか起こらないため, こ れによりキュー長が増加して RED より高いスループット を示していると考えられる。Easy RED は上述のように早 めに確率的な廃棄を行っているので, 高い公平性を示して いるが，総スループットは低く，フローあたりのスループッ 卜も低くなっている。

提案方式は，比較対象とした全ての方式の中で最も高い スループットを示している。これは, 早めの確率的廃棄を 行わず，キュー長がある程度大きくなってから廃棄してい るためと考えられる。そして, フロー数が増加しても, 後 方廃棄のようにスループットが落ち込むことはない。これ は，平均キュー長が閾值を超えることによる廃棄がランダ 厶廃棄に似た廃棄を行っているためと考えられる。公平性 については, Flow RED と同程度の性能を示したが, Easy RED よりは低い性能を示している。しかし，これについて は, Flow RED 以上に高いスループットで公平性を保って いるため，それほど大きな問題とはならないと考えられる。

\section{6. おわりに}

本論文では，RED のパラメー夕を削減し，確率的な廃 棄を行わないパケット廃棄方式を提案し，その有効性につ いて検討した。

本方式では, 平均キュー長算出時の重み係数 $w_{q}$ の值をや や小さく設定して，実キュー長と平均キュー長の間にずれを 生じさせることで，平均キュー長を対象とする䦭值 $\max _{t h}$ による廃棄が擬似的なランダム廃棄となることを利用して いる。そして，本方式が用いている 2 つのパラメー夕 $w_{q}$ と $\max _{t h}$ が，スループットと公平性に及ぼす影響につい て考察した。その結果, max $_{t h}$ よりも $w_{q}$ の方が性能に大 きな影響を与えることが示された。さらに，既存方式との 性能比較を行った結果，本方式は最も高いスループットと Flow RED と同等の公平性を示した。

今後の課題として, 短期の TCP フローや UDP フロー が混在する環境下での有効性，TCP の様々なバージョンと の親和性などの検証が挙げられる。

(平成 22 年 2 月 26 日受付, 平成 22 年 7 月 5 日再受付)

\section{文献}

(1) R. K. Jain, D. M. W. Chiu, and W. R. Hawe: "A Quantitative Measure of Fairness and Discrimination for Resource Allocation in Shared System", DEC (Digtal Equipment Corporation) Research Report, TR-301 (1984-9)

(2) L. Zang and D. Clark: "Oscillating Behavior of Network Traffic: A Case Study Simulation", Internetworking: Research and Experience, Vol.1, No.2, pp.101-112, John Wiley \& Sons (1990)

(3) S. Floyd and V. Jacobson: "Random Early Detection Gateways for Congestion Avoidance", IEEE/ACM Transactions on Networking, Vol.1, No.4, pp.397-413 (1993-8)

4) D. Lin and R. Morris: "Dynamics of Random Early Detection", ACM SIGCOMM Computer Communication Review, Vol.27, No.4, pp.127-137 (1997-10)

(5) F. M. Anjum and L. Tassiulas: "Balanced-RED: An Algorithm to Achieve Fairness in the Internet", Tecnical Research Report, CSHCN (the Center for Satellite and Hybrid Communication Networks) T.R. 99-9 (1999-3)

(6) T. J. Ott, T. V. Lakshman, and L. Wong: "SRED: Stabilized RED", Proceedings of IEEE INFOCOM '99, pp.1346-1355 (1999-3)

(7) S. Floyd, R. Gummadi, and S. Shenker: "Adaptive RED: An Algorithm for Increasing the Robustness of RED's Active Queue Management", available at http://www.icir.org/floyd (2001-8)

(8) L. A. Grieco and S. Mascolo: "TCP Westwood and Easy RED to Improve Fairness in High-Speed Networks", Protocols for High Speed Networks, 7th IFIP/IEEE International Workshop, PfHSN 2002, Berlin, Germany, April 2002, Proceedings, LNCS 2334, pp.130-146, Springer (2002)

(9) A. Fujii and H. Inai: "Performance Comparison of Packet Discarding Schemes in a Router", IEICE Technical Report, IN2008-124 (2009-2) (in Japanese)

藤井敦朗・稲井 寛：「ルータにおけるパケット廃棄方式の性能比 較」, 信学会技報, IN2008-124 (2009-2)

(10) M. Christiansen, K. Jeffay, D. Ott, and F. D. Smith: "Tuning RED for Web Traffic", Proceedings of ACM SIGCOMM '00, pp.139-150 (2000)

11) G. Iannaccone, M. May, and C. Diot: "Aggregated Traffic Performance with Active Queue Management and Drop from Tail", ACM SIGCOMM Computer Communication Review, Vol.31, No.3, pp.4-13 (2001-7)

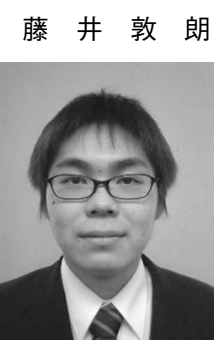

（非会員） 1986 年生。 2008 年 3 月川崎医療福祉 大学医療技術学部医療情報学科卒業。2010 年 3 月岡山県立大学大学院情報系工学研究科博士前期 課程電子情報通信工学専攻修了。同年 4 月 $\mathrm{NTT}$ ソフトウェア (株) 入社。在学中, ルータにおけ るパケット廃棄方式に関する研究に従事。

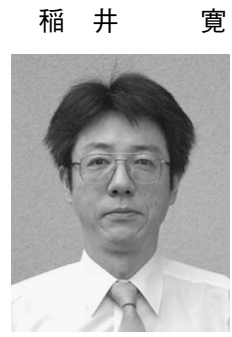

（正員） 1961 年生。1985 年大阪大学基礎工学部 情報工学科卒業。1987 年同大学院博士前期課程修 了。1988 年神戸大学総合情報処理センター助手。 1993 年岡山県立大学情報工学部情報通信工学科 助教授。2000 年同教授, 現在に至る。主として 計算機及び通信システムの性能評価，通信プロト コル，広带域通信網に関する研究に従事。ACM, IEEE，電子情報通信学会, 情報処理学会, シス テム制御情報学会の各会員。工学博士。 